\title{
Water resources and their traditional management in Kedarnath valley of Garhwal Himalaya, India
}

\begin{abstract}
Himalaya has been famous for its water resources, forest diversity, unique wildlife, rich culture and sacred Hindu's shrine. Himalaya, being an abode of various perennial rivers, is considered as a water tower of the Asia. The present study aims was to assess the status of water resources of Kedarnath valley. In the present study, water resources and their traditional management system data were collected through field visit and used various methods that include questionnaire, personal interviews, direct interaction with the villagers and group discussion. Water resources regime in Kedarnath Valley is a product if it's specific environmental condition. Kedarnath Valley revealed that the major sources of water in Kedarnath Valley are rain water, glaciers, rivers, lakes, streams and springs. Prominent lakes are Vasuki Tal, Chorabari Tal, Deoria Tal, Kanchani Tal and Nandi Kund. However, the important glaciers are Chorabari and Panptiya. The important rivers of Kedarnath Valley are Mandakini, Doodh Ganga, Vasuki Ganga, Kali Ganga, Madhmaheswar Ganga and Kakara Gad. Chhal-Khal, Dhara, Kund, Simar, etc. are important water conservation and its management system in Kedarnath valley.
\end{abstract}

Keywords: kedarnath valley, water resources, traditional water management, garhwal himalaya
Volume 3 Issue 3 - 2019

\author{
Chandi Prasad, Ramesh C Sharma \\ Department of Environmental Sciences, H.N.B. Garhwal \\ University, (A Central University), India
}

\begin{abstract}
Correspondence: Chandi Prasad, Department of Environmental Sciences, H.N.B. Garhwal University, (A Central University), Srinagar Garhwal, 246I74, Uttarakhand, India, Email cpsemwaal2@gmail.com
\end{abstract}

Received: March 26, 2019 | Published: May 14, 2019

\section{Introduction}

Himalaya has been famous for its water resources, forest diversity, unique wildlife, rich culture and sacred Hindu's shrine. Himalaya, being an abode of various perennial rivers, is considered as a water tower of the Asia. Ganga and Yamuna are two most sacred rivers of the country; the mighty rivers; Ganga and Yamuna have their sources in the Garhwal Himalaya (Uttarakhand) and make the region a center of pilgrimage since very ancient times. These rivers have been considered as a life for large population of the country, not only satisfying their primary needs of drinking water and food security, but also, fulfilling their other associated needs for performing rituals, navigation, energy and other developmental activities. But, the irony is that the mountain people, who reside in the Garhwal Himalayan region that is considered as water tower, often faces the water scarce condition and inadequate and faulty planning of the government for mountain region. Water is one of the most vital natural resources for sustaining life; and it is likely to become critically scarce in the coming decades, due to continuous raise in its demands, rapid rise in population and expanding economy of the country. Water is a valuable natural resource for sustaining life and environment. It is in a continuous cyclic movement between ocean, land and atmosphere. The hydrological cycle once viewed as plentiful and infinite resource, now has become a scarce resource. Water plays an important role in social and economic development. Variations in climatic characteristics both in space and time are responsible for uneven distribution of precipitation in India.

The water requirement scenario calls for a sustainable development taking into account technical, economical, social, environmental, and institutional factors. Civilizations have even been compelled to shift from the region where water became deficient in amount, inferior in quality and erratic in behavior. ${ }^{1}$ Khulbe $^{2}$ study on the Kamaun Himalaya has brought to light the fact that degraded conditions of most of the watersheds are limiting factors for the development of the region and can be addressed only by the implementation of short and long term strategies for proper development of micro and macro watersheds. There is a need for proper Water Resource Management which would require irrigation management, flood management, water supply facilities, hydro-power, industrial requirement and other uses. A sound and effective water management approach in the Northeast may come to rescue the neighboring countries as well. ${ }^{3}$ Studies made by Singh, Pradhan \& Devi ${ }^{4}$ on the integrated water resource management of Manipur and by Agnihotri ${ }^{5}$ on the legal issues in the management of water in Meghalaya have highlighted the importance of a coordinated approach towards the better utilization of water resources for different objectives - irrigation, hydro-power generation, flood control, transportation and environmental protection and the need for a proper legal framework for water resource management. Rawat and $\mathrm{Shah}^{6}$ studied traditional knowledge of water management in Kumaun Himalaya. Sharma and Kanwar ${ }^{7}$ studied indigenous water conservation system, a rich tradition of rural Himachal Pradesh. Khadse et al. ${ }^{8}$ studied the conservation, development and management of water resources in Himalayan region, India.

Biswas $^{9}$ worked on integrated water resources management and reassessment. Biswas et al., ${ }^{10}$ studied on water as a focus for regional development. Devarapalli ${ }^{11}$ studied on water resource management and socio-cultural adaptations in a river island community. Dhas et al., ${ }^{12}$ worked on water for migrant livestock: Issues, concerns and policy. Singh ${ }^{13}$ studied on equitable gender participation in local water governance: An insight into institutional paradoxes. Singh et al., ${ }^{14}$ worked on integrated water resource management of Manipur. Sharma ${ }^{15}$ worked on sustainable drinking water resources in difficult 
topography of hilly state Uttarakhand. Pattanaaik et al., ${ }^{16}$ studied traditional system of water management in watersheds of Arunanchal Pradesh. Sharma \& Kanwar $^{7}$ studied indigenous water conservation system, a rich tradition of rural Himachal Pradesh. Rawat \& Shah ${ }^{6}$ studied traditional knowledge of water management in Kumaun Himalaya. Khadse et al., ${ }^{8}$ studied the conservation, development and management of water resources in Himalayan region, India. But no contribution is available on water resources management of Kedarnath Valley. Kedarnath Valley came into prominence due to a major hydrological disaster in June 2013. More than 5,000 people lost their lives due to this ecodisaster. Kedarnath Valley is also famous for the world famous Kedarnath Temple dedicated to Lord Shiva.

\section{Materials and methods}

\section{Study area}

Uttarakhand is one of the beautiful hilly states of country located in the Himalaya. The state divided into Garhwal and Kumaun region covering the western part of the Himalaya with latitude $29^{\circ} 26^{\prime}-31^{\circ} 28^{\prime}$ $\mathrm{N}$ and longitude $77^{\circ} 49^{\prime}-80^{\circ} 06^{\prime} \mathrm{E}$ with a total area of $29,089 \mathrm{~km}^{2}$. The
Kedarnath Valley is the main part of Uttarakhand. Kedarnath Valley is located between the coordinates of latitude $30^{\circ} 25^{\prime} 0^{\prime \prime}$ to $30^{\circ} 45^{\prime} 0^{\prime \prime}$ $\mathrm{N}$ and longitude $78^{\circ} 55^{\prime} 0^{\prime \prime}$ to $79^{\circ} 20^{\prime} 0^{\prime \prime}$ E of Ukhimath tehshil in the Rudraprayag district of Garhwal Himalaya, Uttarakhand. The survey was done from altitude of $864 \mathrm{~m}$ above m.s.l to alpine meadow of Kedarnath-Tunganath $(3,680-4,000 \mathrm{~m}$ above m.s.l). This study was carried out in 20 villages of Kedarnath Valley of Ukhimath tehshil (Figure 1). The Kedarnath Valley is in the district of Rudraprayag with an area of $1,248 \mathrm{~km}^{2}$ including 248 villages with a total population of 87,024 including 42,614 males and 44,410 females (Census of India $\left.{ }^{17}\right)$. The forest area of the Kedarnath Valley is rich in the species of Deodar (Cedrus deodara), Kail (Pinus walichiana), Oak (Qurcus incana, Quercus leucotricophora). Buransh (Rhododendron arboretum), Thuner (Taxus baccata), Cheer (Pinus rbullocksburghii), Akhrot (Junlans regia). Kedarnath Valley is very rich in edible plant resources. Kedarnath Valley is also famous for alpine grasslands (Bugyals). There are many beautifully carpeted rich bugyals near Kedarnath and Tunganath temples. The major rivers in Kedarnath Valley are Mandakni, Doodhganga, Saraswati River, Songanga, Kaliganga, Madhuganga and Kakragad. The major lakes are Chorabari lake, Vasuki lake, Kanchanital, deoria tal and Nandi kund lake.

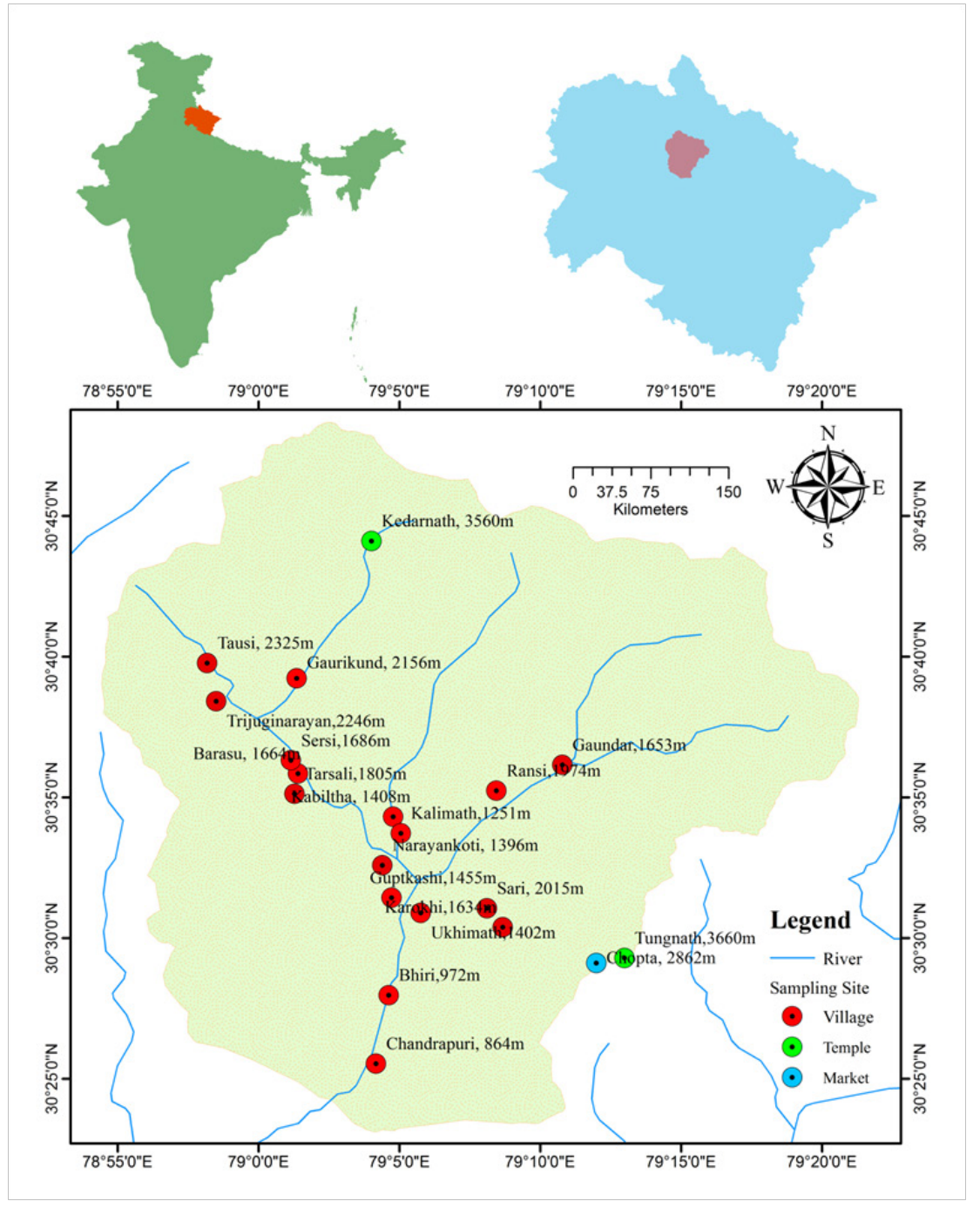

Figure I Location map of the study area:The Kedarnath Valley. 


\section{Methods}

A complete survey was done at household level for each studied villages (Kedarnath, Gaurikund, Trijuginarayan, Taushi, Sersi, Barsau, Tarsali, Narayankoti, Guptakashi, Kabiltha, Kalimath, Ukhimath, Sari, Karokhi, Chupta, Tungnath, Ransi, Gundar, Bhiri and Chandrapuri), covering more than 462 household from 20 villages, with structured and semi structured questionnaires and personal interviews with households. All the studied villages were surveyed in depth and head of family were interviewed and requested to provide information of water resources. Much of the information were collected using structural questionnaires on water resources and their management like form tals/lakes, glaciers, rivers, streams, springs, chal-khal, dhara, naula, kund, simar etc.

\section{Results}

The major sources of water in Kedarnath Valley are rain water, glaciers, rivers, lakes, streams and springs. Kedarnath Valley is located in the monsoon belt. People of this Valley collect water of rain and managed it properly and use it for different purposes.

\section{Water resources in kedarnath valley}

Water resources of Kedarnath Valley are present in the form tals/ lakes, glaciers, rivers, streams, springs, naulas, dharas, khals and chals.

\section{Lakes/Tal}

There are numerous lakes and tals in the Kedarnath Valley. The details of them are given below:

Vasuki tal: Vasuki tal (Vasuki Lake) is located at an elevation of $4,328 \mathrm{~m}$ asl, in the beautiful hills of Kedarnath Valley. In the last 2 to 5 years Vasuki Tal attracted more pilgrims and trekkers. Vasuki Tal is big in size, beautiful in surrounding environment, and also difficult for trekking. Vasuki Tal is surrounded with very high mountain peaks of the Himalaya. There are several types of beautiful, colorful flowers including Brahma Kamal (Saussurea obvallata) around the Vasuki Tal. It is mythological believe that at the time of Rakshabandan (Indian festival) Lord Vishnu took bath in this lake, so it is called Vasuki Tal. Vasuki Tal is a source of Vasuki Ganga or Sone Ganga (Figure 2).

Chorabari tal: At the turn, Chorabari Tal, one of the two snouts of the Chorabari glacier terminates. It is located at a distance of about $3.0 \mathrm{Km}$ from the Kedarnath Temple (Figure 2). Due to the lack of transportation facilities, lake is visited by a few tourists. On the bank of this lake according to yogic legends Shiva, who is considered the Adi Guru (first Guru), transmitted yoga to the Saptarishis, In 1948, some of Mahatma Gandhi's ashes were immersed in the lake, so it is known as Gandhi Sarovar. There is a Bhairava Temple near the Glacier, adjacent to which is a cliff named Bhairava Jhamp. Believing that, it would bring them freedom (mukti), the cliff was placed where devotees leaped off. The practice was banned by the Britishers in the $19^{\text {th }}$ century. Chaurabari Lake is a major source of Mandakini River.

Deoria tal: Deoria Tal is one of the most beautiful lakes having scenic beauty as well as valuable ecosystem services. Deoria Tal is an emerald lake perched at an altitude of $2,438 \mathrm{~m}$ asl. Deoria Tal blesses the tourists with reflections of Chaukhamba peaks on its crystal clear water. At Deoria Tal, one can experience the better of two worlds, the first one being the reflection of the beautiful surroundings on the lake and the other one being the real world. Deoria Tal is also known as Deoriatal or Devariyatal. The lake is located amidst verdant green inclined field surrounded by dense patch of trees. This lake is known as a popular trekking destination in the region; because of its soothing scenic beauty and easy access. The water of Deoria Tal is an important source of water for nearby villages for drinking, animals and irrigation purposes.

Kanchani tal: Kanchani Tal is a high altitude glacial lake located at a distance of $16 \mathrm{~km}$ from Madmaheswar. The pristine lake is located at an elevation of $4,200 \mathrm{~m}$ asl. Surrounds of this small lake are fantastic landscape and Himalayan flowers. One have a wonderful view of the snow-clad Himalayan peaks from the lakeside. The vegetation around Kanchani Tal makes it one of the best tourist places. Kanchani Tal is popular place for trekking.

Nandi kund: Nandi Kund is located at an altitude of $4,800 \mathrm{~m}$ asl. and $14 \mathrm{~km}$ above from Madmaheshwar-Kalpeshwar trail. Lofty snow covered peak and beautiful view of verdant green meadows can be seen on this trail. Besides the Nandi kund, there are very old swords in a temple, which are worshipped, as they are thought to have belonged to the Pandavas. The local people believe that pandavas stayed in Pandav Sera Valley for a long time, digged canal and changed it into a cultivable land, which is a $3-4 \mathrm{~km}$ wide.

\section{Glaciers of Kedarnath valley} Valley.

There are major two glacier Chorabari and Panpatiya in Kedarnath

Chorabari glacier: The Chorabari Glacier is situated in the western extremity of the Central Himalaya $\left(30^{\circ} 46^{\prime} 20.58^{\prime \prime} \mathrm{N}\right.$ and $79^{\circ} 2^{\prime} 59.381^{\prime \prime E}$.) having the southern aspect of Kedarnath Valley (Figure 2). It has an average gradient of $\sim 16^{\circ}$ with total glaciated area around $15 \mathrm{~km}^{2}$. The head of the glacier lies at an elevation of 6,500 $\mathrm{m}$ above m.s.l. whereas, the snout is located at $3,865 \mathrm{~m}$ above m.s.1. ${ }^{18}$ This glacier is the source of the Mandakini River, which eventually joins the Alaknanda River near Rudraprayag. Geologically, the area is situated north of the Pindari Thrust comprises of Calc silicate, Biotite gneisses, and Schist, and Granite pegmatite apatite veins belonging to the Pindari Formation. ${ }^{19}$ Above $3,865 \mathrm{~m}$, glacier processes dominate, whereas between 3,865 and $2,800 \mathrm{~m}$ above m.s.l. is dominated by glacio-fluvial processes.

Panpatia glacier: Forming a bridge between two most important Hindu pilgrimage sites, Kedarnath and Badrinath, at an elevation of $4,200 \mathrm{~m}$ asl., the Panpatia Col is one of the high altitude mountain passes that gets across the Panpatia Glacier (Figure 2). It is surrounded by several major peaks of the Garhwal Himalay.

\section{Rivers and streams:}

The Mandakini is the major river flowing in the Kedarnath valley. In addition this major River, there are five major tributaries of Mandakini in the Kedarnath Valley.

Mandakini: Mandakini is a tributary of the Alaknanda River. Mandakini originates from the Chorabari Glacier near the Kedarnath Temple in Rudraprayag district of Garhwal Himalaya (Figure 2). Mandakini meets with the Vasukiganga Ganga at Sonprayag, Kali Ganga at Guptakashi, Madmaheswar Ganga at Kund, Kakra Gad at Kakra and Laster Gad at Tilwara and at last it joins Alaknanda at Rudraprayag. Mandakini River and its tributaries are important rivers for villagers for different purposes. The Mandakini River has a length 
of $75.25 \mathrm{~km}$ from Chaurabari glacier to Rudraprayag confluence. Mandakini River turns violent during monsoon season, causing havoc in the nearby villages and destroys the parts of National Highway in Rudraprayag district. The flash floods in Kedarnath Valley in June 2013, was caused by this river only. Mandakini River has 7 order drainage basins and the maximum frequency is in first order streams. Stream numbers are the number of stream segments in each stream order. It is obtained by dividing the sum length of stream of an order by total number of segments in the order. The main stream length of Mandakini River is $75.25 \mathrm{Km}$ and of V and VI orders are $107.52 \mathrm{Km}$ and $75.05 \mathrm{Km}$ respectively. While, significant changes have been found in I $(3,841.62 \mathrm{Km})$, II $(966.69 \mathrm{Km})$, III $(430.56 \mathrm{Km})$ and VII $(30.82 \mathrm{Km}){ }^{20}$ (Table 1) (Figure $\left.3 \& 4\right)$.

The prefix "mand" (Sanskrit) means "calm" and "unhurried", and
Mandakini thus signifies "she who flows calmly". The Mandakini is mentioned as one of the transcendental rivers in the holy religious work Srimad Bhagavatam.

Doodh ganga: Doodh Ganga is a small tributary of Mandakini River in Kedarnath shrine. It has a small length (approx $5 \mathrm{~km}$ ) from its source. The Doodh Ganga originates from Vasuki Tal located behind the western mountain of Kedarnath town (Figure 2). Doodh Ganga joins Mandakini River after $5 \mathrm{~km}$ distance from the source (below the Kedarnath Temple) (Figure 2). The name of the river is considered to be due to its milky colour. There is a hydropower house at this small tributary, which supplies the electricity in Kedarnath Dham and surrounding areas. This river is also one of the best sources of water supply in Kedarnath Dham.
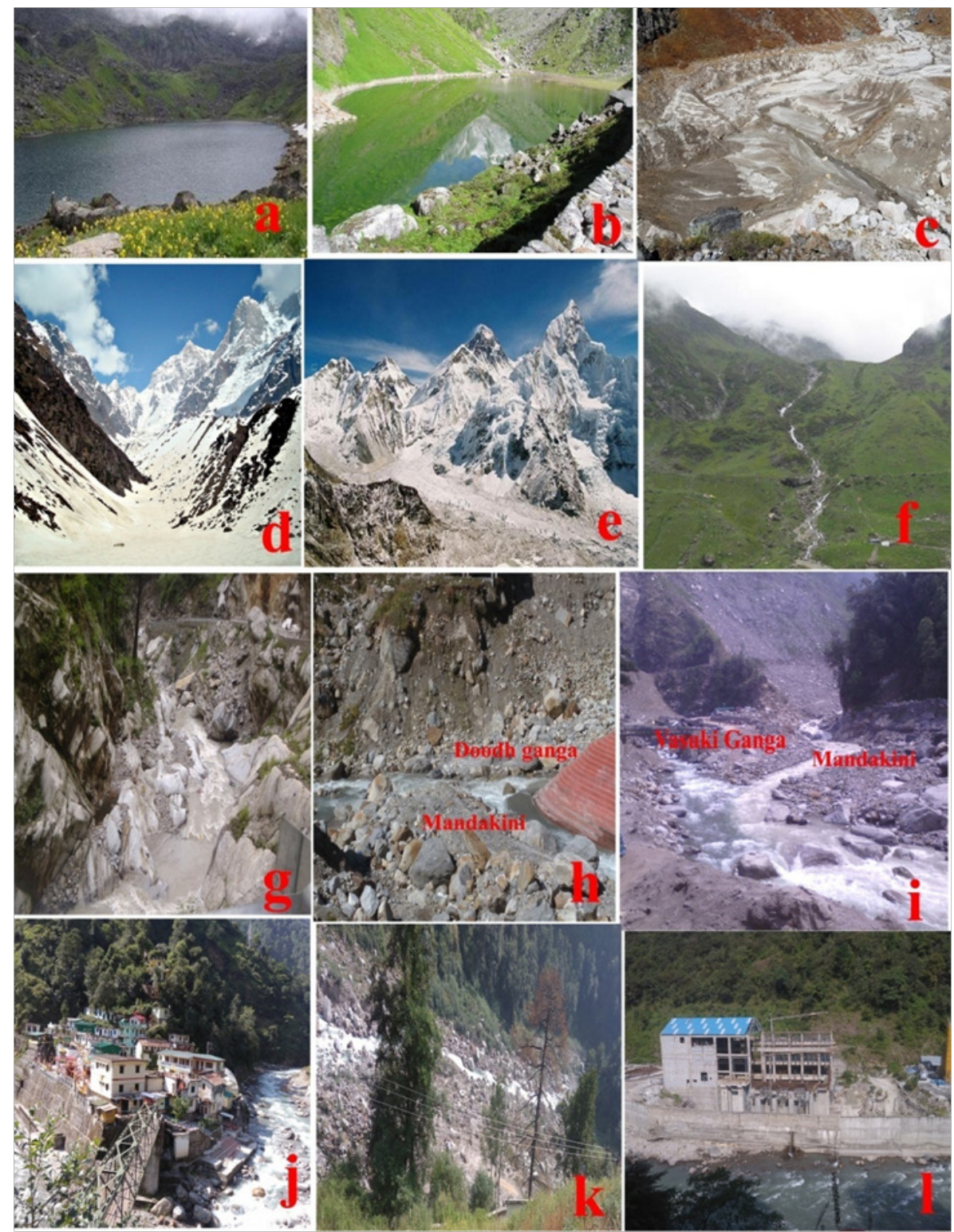

Figure 2 Different water resources: (a) Vasuli lake; (b) Chorabari lake before disaster; (c) Chorabari lake after disaster; (d) Chorabaro glacier; (e) Panipatiya glacier; (f) Doodh Ganga; (g) Mandakini River; (h) Confluence of Mandakini and Dhoodh ganga; (i) Confluence of Mandakini and Vashuki ganga; (j) Kali ganga; (k) Madmaheswar ganga; (l) Mandakini River. 


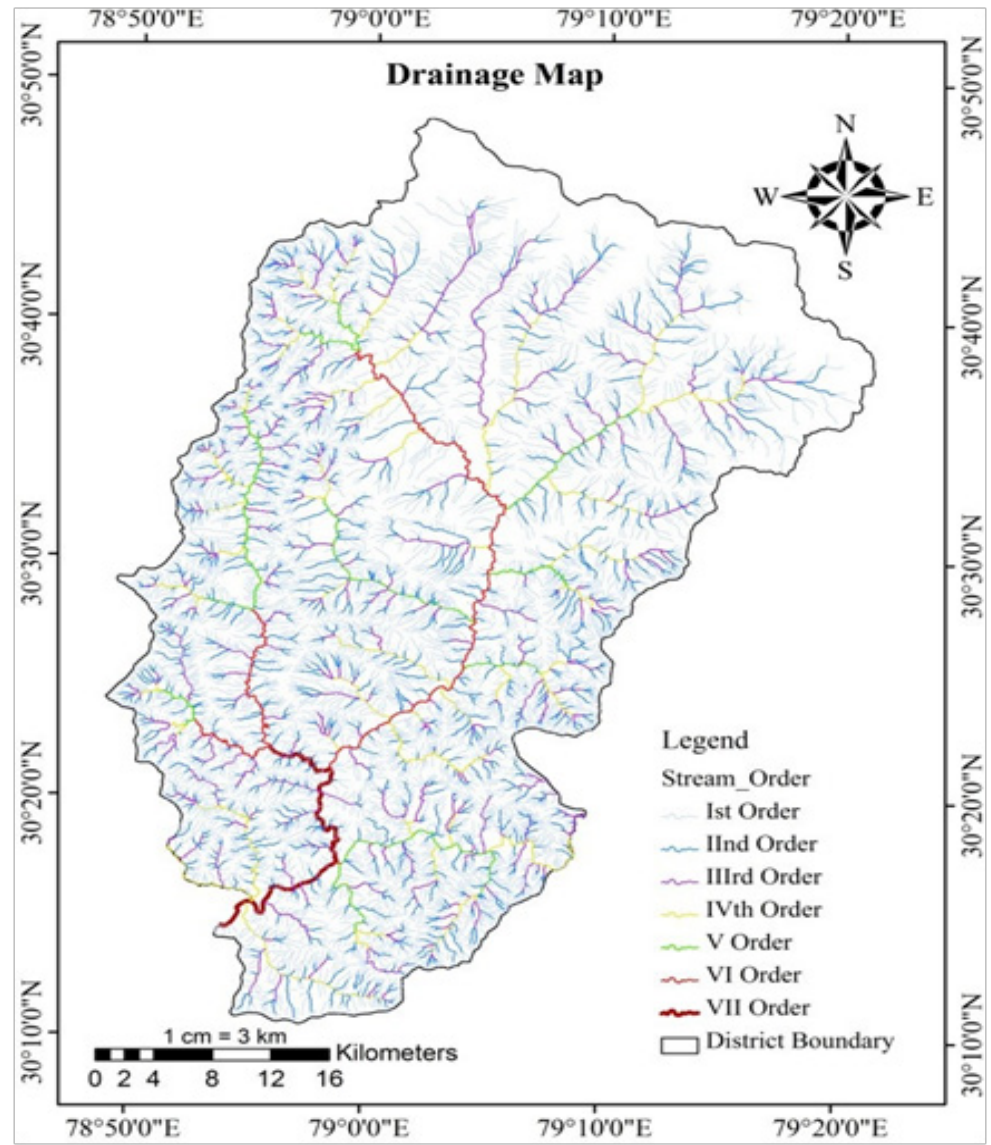

Figure 3 Drainage map of the Mandakini River, Kedarnath Valley.

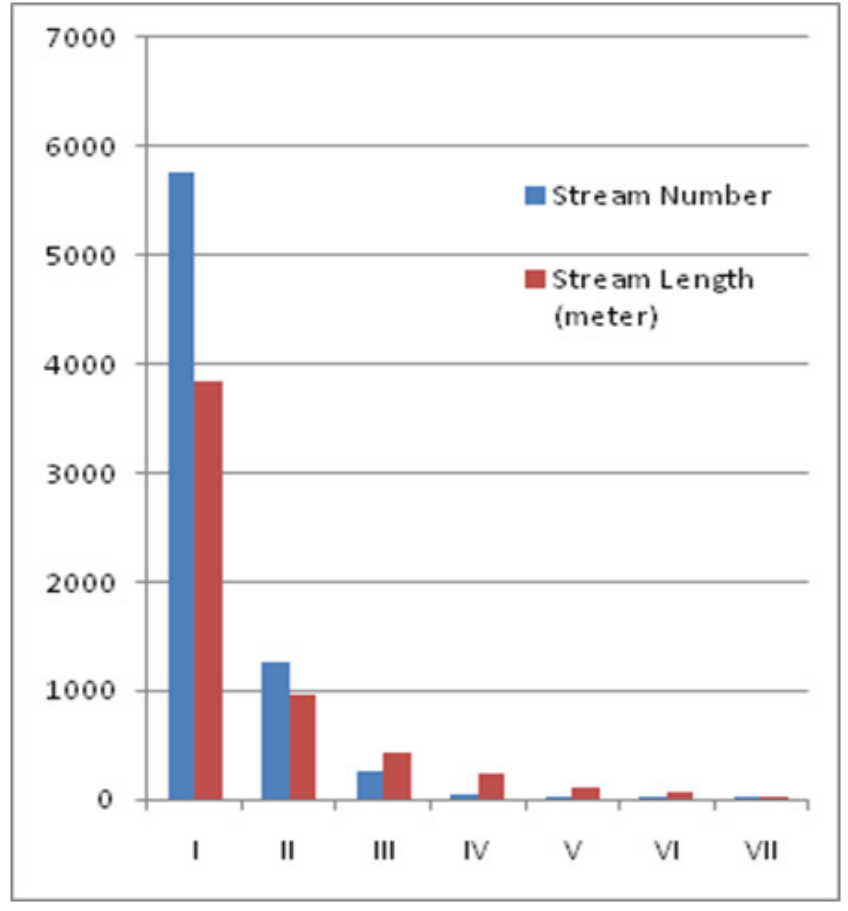

Figure 4 Stream lengths and stream segments in Kedarnath Valley. 
Vasuki ganga: Vasuki Ganga is a tributary of the Mandakini River. The source of the Vasuki Ganga is the Vasuki Tal, a small glacial lake located in the glacial trough east of Chor Gamak glacier, near Kedarnath. Vasuki Ganga also called as Songanga is a small stream.

Table I Stream order, number of streams, stream lengths and main channel length of the Mandakini River

\begin{tabular}{llll}
\hline Stream order & Number of streams & Stream length $(\mathbf{K m})$ & Length of main channel $(\mathrm{Km})$ \\
\hline I & 5,75 I & $3,841.62$ & \\
II & 1,266 & 966.69 & \\
III & 27 I & 430.56 & \\
IV & 52 & 241.09 & 75.25 \\
V & 12 & 107.52 & \\
VI & 4 & 75.05 & \\
VII & 1 & 30.82 & \\
Total & 7,157 & $5,693.34$ & \\
\hline
\end{tabular}

Kali ganga: Kali Ganga originates from Kham Glacier and Mardin Glacier. This is a tributary of Mandakini River (Figure 2). Confluence of Kaliganga and Mandakini is at Rinkot known as Triveni. The water of Kali Ganga is important source of water for nearby villages for drinking, animals and agriculture purposes.

Madmaheswar ganga/Madhu ganga: Madmaheswar Ganga is also a tributary of Mandakini River. Nandi Kund near the Madmaheswar Temple is a source of Madmaheswar Ganga (Figure 2). Madmaheswar Ganga is lifeline for Gaundar, Ransi, and other nearby villages for meeting the water requirements. Confluence of Madmahswar and Mandakini is at Rinkot near Guptkashi town. There is a hydropower house at this tributary, which supplies electricity in Gaundar village.

Kakra gad: The Kakra Gad originates from Chandrashila. This is an another tributary of Mandkini River, which joins Mandakini at Kakra Gad. Kakra gad is an important stream for Sari and other nearby villages for different purposes.

\section{Physico-chemical parameters of Mandakini River}

Goswami \& Singh ${ }^{21}$ studied the physico-chemical parameters of Table 2 Physico-chemical characteristics of water of the Mandakini River in Kedarnath Valley

\begin{tabular}{|c|c|c|c|c|c|c|c|c|c|c|c|c|c|}
\hline Parameters & Jan & Feb & Mar & Apr & May & Jun & Jul & Aug & Sep & Oct & Nov & Dec & Mean $\pm S D$ \\
\hline \multirow{2}{*}{ AT $\left({ }^{\circ} \mathrm{C}\right)$} & 12.33 & 17.67 & 22.83 & 26 & 26.83 & 27.5 & 27.67 & 25.83 & 26.67 & 22.17 & 17.83 & 13.67 & 22.25 \\
\hline & \pm 1.53 & \pm 1.53 & \pm 1.04 & \pm 0.87 & \pm 1.26 & \pm 2.00 & \pm 1.61 & \pm 1.76 & \pm 1.61 & \pm 1.76 & \pm 0.76 & \pm 1.26 & \pm 5.54 \\
\hline \multirow{2}{*}{ WT $\left({ }^{\circ} \mathrm{C}\right)$} & 9.83 & 12.67 & 14.33 & 16.17 & 16.5 & 17.33 & 19.67 & 18.83 & 19 & 15.5 & 13.33 & 10 & 15.26 \\
\hline & \pm 1.44 & \pm 1.53 & \pm 1.53 & \pm 1.15 & \pm 1.50 & \pm 2.02 & \pm 1.53 & \pm 2.25 & \pm 1.80 & \pm 1.32 & \pm 1.26 & \pm 1.00 & \pm 3.32 \\
\hline \multirow{3}{*}{$\mathrm{VL}(\mathrm{m} \mathrm{sec}-1)$} & 0.33 & 0.41 & 0.41 & 0.47 & 0.44 & 0.51 & 0.78 & 0.6 & 0.54 & 0.5 & 0.47 & 0.47 & 0.49 \\
\hline & & & & & & & & & & & & & \\
\hline & \pm 0.02 & \pm 0.05 & \pm 0.07 & \pm 0.00 & \pm 0.03 & \pm 0.08 & \pm 0.06 & \pm 0.03 & \pm 0.04 & \pm 0.04 & \pm 0.02 & \pm 0.04 & \pm 0.11 \\
\hline \multirow{2}{*}{ TR (m) } & 0.36 & 0.31 & 0.33 & 0.34 & 0.35 & 0.22 & 0.11 & 0.21 & 0.27 & 0.34 & 0.37 & 0.39 & 0.3 \\
\hline & \pm 0.00 & \pm 0.02 & \pm 0.02 & \pm 0.01 & \pm 0.02 & \pm 0.03 & \pm 0.01 & \pm 0.03 & \pm 0.01 & \pm 0.03 & \pm 0.02 & \pm 0.01 & \pm 0.08 \\
\hline \multirow{2}{*}{ TH (mg l') } & 48.17 & 51.67 & 41.83 & 36.67 & 32.33 & 33.17 & 33.33 & 39.67 & 34.83 & 43.5 & 42 & 50.17 & 40.61 \\
\hline & \pm 3.55 & \pm 2.31 & \pm 1.04 & \pm 0.29 & \pm 1.53 & \pm 3.01 & \pm 1.44 & \pm 1.44 & \pm 1.61 & \pm 1.80 & \pm 2.00 & \pm 2.84 & \pm 6.80 \\
\hline
\end{tabular}

the water of Mandakini River. Seasonally, average highest $\left(26.92^{\circ} \mathrm{C}\right)$ air temperature was recorded during monsoon and lowest $\left(16.5^{\circ} \mathrm{C}\right)$ in winter. Average highest $\left(18.71^{\circ} \mathrm{C}\right)$ water temperature was recorded during monsoon and lowest $\left(12.17^{\circ} \mathrm{C}\right)$ in winter. Average maximum $\left(0.61 \mathrm{~m} \mathrm{sec}^{-1}\right)$ current velocity was recorded during monsoon and minimum $\left(0.43 \mathrm{~m} \mathrm{sec}^{-1}\right)$ during summer. Maximum $\left(82.67 \mathrm{mg}^{-1}\right)$ total alkalinity was recorded during winter and minimum $(36.17 \mathrm{mg}$ $\left.1^{-1}\right)$ in summer. Maximum total hardness $\left(45.96 \mathrm{mg} \mathrm{l}^{-1}\right)$ was recorded during winter and minimum $\left(35.25 \mathrm{mg}^{-1}\right)$ during monsoon. Average highest dissolved oxygen $\left(9.61 \mathrm{mg}^{-1}\right)$ was recorded in winter and lowest $\left(8.97 \mathrm{mg} \mathrm{1}^{-1}\right)$ in monsoon. Free Carbon dioxide fluctuated between $1.91 \pm 0.25$ and $2.73 \pm 0.01 \mathrm{mg} \mathrm{l}^{-1}, \mathrm{pH}$ of river water fluctuated between $7.14 \pm 0.07$ to $7.63 \pm 0.05$. Phosphates range from $0.077 \pm 0.000$ to $0.102 \pm 0.007 \mathrm{mg} \mathrm{l}^{-1}$. Maximum $\left(0.0173 \mathrm{mg} \mathrm{l}^{-1}\right)$ nitrate was recorded during monsoon and minimum $\left(0.0118 \mathrm{mg}^{-1}\right)$ in summer. Maximum turbidity $(185.33 \pm 4.48 \mathrm{NTU})$ of Mandakini water was recorded during monsoon. Seasonally, average highest $(138.95 \mu \mathrm{S} \mathrm{cm}-1)$ conductivity was recorded during summer and minimum $(92.92 \mu \mathrm{S}$ $\mathrm{cm}^{-1}$ ) in monsoon (Table 2).
Confluence of Vasuki Ganga and Mandakini River is known as Sonprayag or Vasuki Prayag (Figure 2). It is located at $14 \mathrm{Km}$ downstream from the famous Triyuginarayan Temple. 


\begin{tabular}{|c|c|c|c|c|c|c|c|c|c|c|c|c|c|}
\hline Parameters & Jan & Feb & Mar & Apr & May & Jun & Jul & Aug & Sep & Oct & Nov & Dec & Mean $\pm S D$ \\
\hline \multirow{2}{*}{$\mathrm{DO}\left(\mathrm{mg}^{-1}\right)$} & 9.91 & 9.62 & 8.98 & 9.33 & 9.09 & 8.9 & 8.87 & 9.02 & 9.09 & 9.02 & 9.49 & 10.03 & 9.28 \\
\hline & \pm 0.15 & \pm 0.17 & \pm 0.32 & \pm 0.08 & \pm 0.12 & \pm 0.08 & \pm 0.05 & \pm 0.17 & \pm 0.12 & \pm 0.03 & \pm 0.06 & \pm 0.00 & \pm 0.40 \\
\hline \multirow{2}{*}{$\mathrm{FCO}_{2}\left(\mathrm{mg} \mathrm{l}^{-1}\right)$} & 2.01 & 2.2 & 2.2 & 2.73 & 1.91 & 2.02 & 2.16 & 2.54 & 2.31 & 2.09 & 2.18 & 2.09 & 2.2 \\
\hline & \pm 0.11 & \pm 0.09 & \pm 0.19 & \pm 0.01 & \pm 0.25 & \pm 0.13 & \pm 0.13 & \pm 0.11 & \pm 0.00 & \pm 0.22 & \pm 0.14 & \pm 0.22 & \pm 0.23 \\
\hline \multirow{2}{*}{$\mathrm{pH}$} & 7.63 & 7.56 & 7.34 & 7.44 & 7.46 & 7.36 & 7.32 & 7.19 & 7.17 & 7.2 & 7.14 & 7.26 & 7.34 \\
\hline & \pm 0.05 & \pm 0.07 & \pm 0.11 & \pm 0.06 & \pm 0.02 & \pm 0.05 & \pm 0.13 & \pm 0 & \pm 0.03 & \pm 0.02 & \pm 0.07 & \pm 0.08 & \pm 0.16 \\
\hline \multirow{3}{*}{ Phosphates ( $\mathrm{mg}$ I } & 0.082 & 0.081 & 0.081 & 0.077 & 0.08 & 0.082 & 0.102 & 0.088 & 0.083 & 0.081 & 0.083 & 0.084 & 0.084 \\
\hline & & & & & & & & & & & & & \\
\hline & 0.0007 & \pm 0.0007 & \pm 0.0005 & \pm 0.000 & \pm 0.001 & \pm 0.0009 & \pm 0.007 & \pm 0.008 & \pm 0.0004 & \pm 0.0008 & 0.002 & \pm 0.001 & \pm 0.006 \\
\hline \multirow{3}{*}{ Nitrates $\left(\mathrm{mg} \mathrm{H}^{-1}\right)$} & 0.011 & 0.012 & 0.012 & 0.012 & 0.012 & 0.018 & 0.02 & 0.018 & 0.013 & 0.012 & 0.012 & 0.012 & 0.014 \\
\hline & & & & & & & & & & & & & \\
\hline & \pm 0.0002 & \pm 0.0003 & \pm 0.0001 & \pm 0.0003 & \pm 0.0005 & \pm 0.0008 & \pm 0.0014 & \pm 0.0003 & \pm 0.0006 & \pm 0.0007 & \pm 0.0007 & \pm 0.0006 & \pm 0.003 \\
\hline \multirow{2}{*}{ TA (mg l-1) } & 70 & 68.75 & 57.75 & 54.5 & 46.92 & 38 & 36.17 & 52.42 & 50.33 & 56 & 63.5 & 82.67 & 56.42 \\
\hline & \pm 2.50 & \pm 2.50 & \pm 4.13 & \pm 2.60 & \pm 4.16 & \pm 2.29 & \pm 2.25 & \pm 2.24 & \pm 2.02 & \pm 3.04 & \pm 5.41 & \pm 5.01 & \pm 13.40 \\
\hline \multirow{2}{*}{ TUR (NTU) } & 0.17 & I & 2.17 & 1.67 & 6 & 157.5 & 185.33 & 57 & 8.83 & 3.83 & 2 & 0.67 & 35.51 \\
\hline & \pm 0.29 & \pm 0.00 & \pm 0.58 & \pm 0.58 & \pm 0.50 & \pm 4.82 & \pm 4.48 & \pm 3.00 & \pm 0.29 & \pm 0.58 & \pm 0.50 & \pm 0.29 & \pm 65.65 \\
\hline \multirow{3}{*}{$\operatorname{CON}\left(\mu \mathrm{S} \mathrm{cm}^{-1}\right)$} & 118 & 122.17 & 144.67 & 150.7 & 135.12 & 103.1 & 82.07 & 87 & 99.5 & 108.88 & 116.17 & 122.33 & $\mid 15.81$ \\
\hline & & & & & & & & & & & & & \\
\hline & \pm 1.32 & \pm 3.79 & \pm 5.75 & \pm 1.56 & \pm 10.19 & \pm 5.43 & \pm 11.38 & \pm 11.44 & \pm 14.91 & \pm 8.31 & \pm 6.45 & \pm 1.76 & \pm 21.22 \\
\hline
\end{tabular}

Acronyms:AT,Air Temperature;WT-Water Temperature;TR, Transparency;VL,Velocity;TA, Total Alkalinity;TH,Total Hardness; DO, Dissolved Oxygen; FCO2, Free Carbon Dioxide; pH-pH,TUR-Turbidity; CON, Conductivity. Sources: Goswami and Singh, 2018.

Traditional water resources management of Kund is closed on three sides and is covered with a roof of stone slabs. Kedarnath valley

Kedarnath Valley is known for various types of traditional water systems, which are used for daily water needs. Apart from Kedarnath Valley, names of these structures may vary in different parts of Uttarakhand. The construction of dhara, naula, chal-khal, simar and dhaab is one of the most common conventional water conservation devices used by the villages. Most respondents have expressed their experience in traditional water management from various techniques. The people of the Valley develop water harvesting devices according to their need and use them for drinking water and irrigation purposes. Local people had the right to use the water of these traditional devices. Equitable water is shared by the people.

\section{Dhara}

Dhara is a common source of drinking water in Kedarnath Valley. It is also called as Panjera Kedarnath Valley. It is basically a drinking water source. Water from springs or subterranean sources is channeled out through carved outlets. The latter are frequently in the shape of a simple channel, shape of elephant, cow, ox (Nandi) and lion face masks. The figure of the outlet is such that even with low water pressure, water can be easily drunk (Figure 5A-5B).

\section{Kund INaulas}

Kunds are situated in most of the Kedarnath Valley, around the world famous Kedarnath temple. They are used to fulfill requirement of the clean drinking water. These water sources are the wonders of the traditional hydraulic technology. Some kunds have modified ornate structures which are used for bathing and washing clothes. Many naulas have a similar basic design. The well is constructed in the form of an inverted trapezoid. The lowest step basically outlines an area of $30 \mathrm{~cm} \times 30 \mathrm{~cm}$, which increases to about $2 \mathrm{~m} \times 2 \mathrm{~m}$ at the top. It is opened on the fourth side. Some kunds are open in three sides (Figure 5E-5K).

\section{Chaal-Khal (Tal)}

A variety of natural and artificial formations or depressions in the mountain regions are used for store of glacier water and rainwater harvesting. They are known as chaals and khals or tals. Basically Khals are found along the top of mountain ridges in the saddle between two crests. They were formed in the past by the glacial action of snowmelt, and rain water, resulting in the formation of lakes with a relatively thick soil bed. Khals store several thousand cubic meter of water. The stored water is used for drinking, domestic purposes and agriculture. It also seeps through pore spaces, fissures and fractures in the underlying aquifers to recharge groundwater, springs (dhara), at lower altitude. Chaals are also found on mountain ridge tops in the saddle between two crests. They are natural and man-made.

\section{Dhaab}

$D h a a b$ is another natural water harvesting structure in Kedarnath Valley. Dhaab is an important source of drinking water for animals and human use like washing clothes and utensils in Kedarnath Valley. The dhaabs are rudimentary structures, found in the high-altitude areas of Kedarnath Valley, Dhaabs store water from springs (dhaara) or it oozes (chhuyan) out from the Earth. In the Kedarnath Valley, birds and wild animals depend on these structures as well in Kedarnath Valley.

\section{Symalu}

Symalu is also known as Simar. Symalu is a marshy tract of land in an agriculture field when is also common in Kedarnath Valley. Symulus are created by the ground water. Symalus are aptly suited for paddy cultivation. Cultivation of high quality crops like paddy, millet, herbs and medicinal plants are common feature in Symalu. 

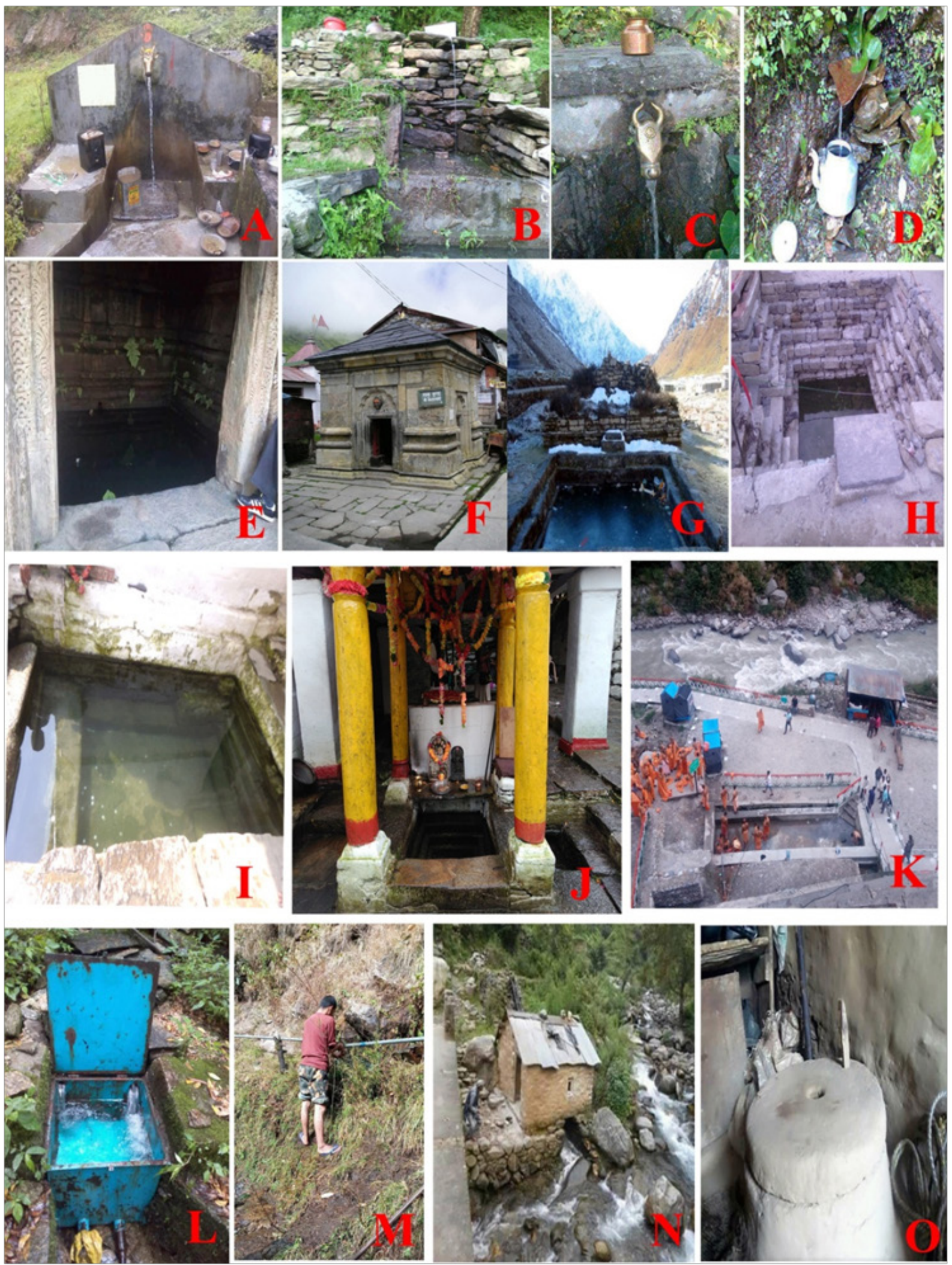

Figure 5 Different traditional water resources: (A-D) Dhaara; (E) Naula; (F) Udak Kund; (G) Hansa Kund; (H) Brahma Kund; (I) Rudra Kund; (J) Narayan Kund; (K) Gaurikund; (L) Tab water; (M) Repair pipeline by villager; (N) Water mill (ghatt); (O) Traditional Grinder (Jandra). 


\section{Kuhl/Guhl}

Archaeological excavations show that terraced agriculture has been practiced in the Central Himalaya for a thousand of years. The problem of irrigating the terraces has been historically resolved by diverting water from nearby mountain streams through channels known as kuhl or guhls in Kedarnath Valley. There are two types of Guhls: kachi kuhls or pakki kuhls. Kachi kuhls are made up of sand, soil and stone. These are constructed traditionally by local people. It has a dug-out earthen main channel-about a few hundred meters to a few kilometers long followed by several field channels and distribution points. Pakki kuhls are cemented and permanent diversion structures. These are constructed by the state government. It has also a dug-out earthen main channel-about a few hundred meters to a few kilometers long followed by several field channels and distribution points. These are small gravity flow irrigation channels that gently traverse the contours of a mountain slope. Though kuhls or guhls are primarily meant for irrigation, some other uses of $k u h l$ are driving the water from streams to gharats (water mills) for grinding of wheat and other grans, drinking and other domestic or animal purposes.

\section{Role of women in water resource management}

In Kedarnath Valley, women play an important role in fetching the water from dhara, stream, pond and river for drinking, domestic animals and agricultural uses. Women have less significant role than men in management, problem analysis and decision making process related to water resources. Women also play a key role in water conservation, cleaning of water source and distribution of water for other families in Kedarnath Valley. However, making kuls or guls, working in ghatts and repairing dharas, maintaining guls and pipelines are the works of men.

\section{Discussion}

Several workers and agencies have contribution on water resources of the Uttarakhand. Geological Survey of India ${ }^{22}$ reported that the glaciers, lakes, streams, rivers and springs contribute as a most important part of surface water resources. A total 968 Himalayan glaciers are important which have $213.74 \mathrm{~km}^{3}$ total ice volume and cover $31,449.3 \mathrm{~km}^{2}$ basin area and $2,883.37 \mathrm{~km}^{2}$ (i.e. $9.17 \%$ ) glaciered area including Gangotri glacier, Khatling glacier, Chorbani glacier and Nandadevi glacier. ISRO ${ }^{23}$ reported 10,3882ha the total wetlands area in the Uttarakhand including 231 ha of high altitudinal lakes i.e. $0.22 \%$ of total wetland area for 118 lakes which covers $<1 \%$ of total wetland area of the Uttarakhand. The lakes (Tals) in upper parts and middle Himalaya form an important part of total drainage system. Sat Tal and Bhimtal of Nainital in Kumaun region are the most important sources for irrigation and drinking purposes. Some of the glacial lakes are Rupkund, Hemkund and Vasuki Tal, whereas Bhimtal, Nainital, Naukuchia Tal, Nachiketa Tal and Dodi Tal are the prominent lakes of middle Himalaya. ${ }^{23}$ Uttarakhand is a hilly state, therefore there are several natural and man-made water sources. Lakes, springs (gadheras), dug wells, tube wells, rivers, river banks and filtration units are the important drinking and irrigation water sources. Chal and khal are also supplying water for rural areas. Uttarakhand Jal Sansthan, which is a key water supply department of the state has rejuvenated 1,804 khals from 2000 to 2008. Pauri district has a maximum number of khals. ${ }^{24}$ After, the study of year-wise discharge data of springs of the state for the year 2005, 2006 and 2008, Uttarakhand Jal Sansthan has reported that Almora district of Kumaun region has maximum number of this type of water sources. ${ }^{24}$.
Vani \& Asthana $^{25}$ reported water rights and policy in Uttarakhand. Upadhayay et al., ${ }^{26}$ reported water management in social development of Uttarakhand. Kala \& $\mathrm{Kala}^{27}$ contributed on indigenous water conservation technology in Sumari village of Uttarakhand. Dorjee \& $\mathrm{Singh}^{28}$ reported traditional irrigation and water distribution system in Ladakh. Khadse et al., ${ }^{8}$ reported conservation, development and management of water resources in Himalaya, Chandra ${ }^{29}$ reported planning for integrated water resources development project with special reference to conjunctive use of surface and groundwater resources. Pattanaaik et al., ${ }^{16}$ contributed on traditional system of water management in watersheds of Arunanchal Pradesh. Sharma \& $\mathrm{Kanwar}^{7}$ studied indigenous water conservation system, a rich tradition of rural Himachal Pradesh. Rawat \& Shah $^{6}$ reported traditional knowledge of water management in Kumaun Himalaya. Sharma \& $\operatorname{Kanwar}^{7}$ have also reported Naulas in Himachal Pradesh. Upadhyay \& Bisht ${ }^{30}$ worked on Naulas and they found the Naula as public property resources. Radhakrishnan ${ }^{31}$ reported guhls of the Garhwal and Kumaun region. In Uttarakhand, guhls accounted for about $42 \%$ of the total net irrigated area. Sharma \& $\mathrm{Kanwar}^{7}$ reported Symalu, simar and gajar in Kumaon Himalaya. Panday \& Chauhan $^{32}$ reported gharats in Kumon and Garhwal regions. They have recorded 60,000 gharats from Uttarakhand. About 5,000 gharats still survive in Almora district and approximately 2,956 in the Garhwal region.

\section{Conclusion}

The present study on the water resources in Kedarnath Valley revealed that the major sources of water in Kedarnath Valley are rain water, glaciers, rivers, lakes, streams and springs. Prominent lakes are Vasuki Tal, Chorabari Tal, Deoria Tal, Kanchani Tal and Nandi Kund. However, the important glaciers are Chorabari and Panptiya. The important rivers of Kedarnath Valley are Mandakini, Doodh Ganga, Vasuki Ganga, Kali Ganga, Madhmaheswar Ganga and Kakara Gad. Traditional water resources management plays an important role in maintaining water resources of Kedarnath Valley during the period of water crisis. It was also observed that in spite the several benefits of these traditional devices, these are being abandoned. Traditional water resources are being damaged due to some natural and anthropogenic activities. Earthquakes and landslides are the main natural factors, while the water resource are being deplete due to all wealth road widening, developing hydropower projects channels and other developmental projects. There is a need to take serious steps for effective maintenance and revival of this traditional wisdom for development, conservation and management of water resources.

\section{Acknowledgments}

Authors are thankful for the local people of the Kedarnath Valley to share their valuable knowledge and help in data collection. One of the authors (Chandi Prasad) thankfully acknowledges the University Grants Commission, New Delhi and H.N.B. Garhwal University (A Central University) for providing University fellowship for undertaking the present work.

\section{Conflicts of interest}

The authors declare that there are no conflicts of interest.

\section{References}

1. Mahajan KK. Management of Surface Water for National Prosperity: An Ecosystem Approach. In: Agarwal VP, et al, Editors. Management of Aquatic Ecosystems. Delhi: Narendra Publishing House. 1989. 
2. Khulbe RD. Water and Aquatic Resources of Kamaun Himalaya: Problems and Management. In: Agarwal VP, et al, Editors. Management of Aquatic Ecosystems. Delhi: Narendra Publishing House. 1989.

3. Mitra AK. Need for Proper Water Resources Management in North-East India. In: Datta B Ray \& Athparia RP, Editors. Water and Water Resource Management. New Delhi: Omsons Publications. 1999.

4. Singh RB, Pradhan B, Devi AS. Integrated Water Resource Management of Manipur. In: Datta B \& Ray RP, Editors. Water and Water Resource Management. New Delhi: Omsons Publications. 1999.

5. Agnihotri SK. Legal Issues in the Management of Water in Meghalaya. In: Datta B Ray \& Athparia RP, Editors. Water and Water Resource Management. New Delhi: Omsons Publications. 1999.

6. Rawat AS, Sah R. Traditional knowledge of water resource management in Kumaon Himalaya. Indian Journal of Traditional Knowledge. 2009;8(2):249-254.

7. Sharma K, Kanwar P. Indigenous water conservation system-A rich tradition of rural Himachal Pradesh. Indian Journal Traditional Knowledge. 2009;8(4):570-573

8. Khadse GK, Talkhande AV, Kelkar PS, et al. Conservation, developmen and management of water resources: An experience in Himalayan region, India. International Water Resources and Arid Environment. 2011;1(3):193-199.

9. Biswas A. Integrated water resources management and reassessment Water International. 2004;29(2):248-256.

10. Biswas A, Unver O, Tortajada C. Water as a focus for regional development New Deli: Oxford University Press. 2004.

11. Devarapalli J. Water Resource Management and Socio-Cultural Adaptation in a River Island Community. Anthropologis. 2006;8(3):197-202.

12. Dhas M, Vivek K, Phansalkar S. Water for Migrant Livestock: Issues, Concerns and Policy. Livestock Research for Rural Development. 2006;18(9):135

13. Singh N. Equitable Gender Participation in Local Water Governance: An Insight into Institutional Paradoxes. Water Resource Management. 2008;22(7):925-42.

14. Singh CR, Thompson JR, French JR. Modelling water-leve options for ecosystem services and assessment of climate change: Loktak Lake, Northeast India. Journal des Sciences Hydrologiques. 2011;56(8):1518-1542.

15. Sharma B. Sustainable Drinking Water Resources in Difficult Topography of Hilly State Uttarakhand. India American Journal of Water Resources. 2016;4(1):16-21.

16. Pattanaaik SK, Sen D, Kuame N, et al. Traditional system of wate management in watersheds of Arunanchal Pradesh. Indian Journal Traditional Knowledge. 2012;11(4):719-723.
17. Census of India. District Census Handbook Rudraprayag. Directorate of Census operations Uttarakhand. 2011;6(12B):1-156.

18. Mehta M, Majeed Z, Dobhal DP, et al. Geomorphological evidences of post-LGM glacial advancements in the Himalaya. A study from Chorabari Glacier, Garhwal Himalaya, India. Journal Earth System Science. 2012;121(1):149-163.

19. Valdiya KS, Paul SK, Chandra $T$, et al. Tectonic and lithological characterization of Himadri (Great Himalaya) between Kali and Yamuna rivers, Central Himalaya. Himalayan Geol. 1999;20:1-17.

20. Kumar A, Negi M. Physiographic study of Mandakini Valley (Rudraprayag District) Garhwal Himalaya by morphometric analysis and geospatial techniques. International Journal of Geomatics and Geosciences. 2016;7(2):128-142.

21. Goswami G, Singh D. Water quality and function of Mandakini River ecosystem of Central Himalaya. International Journal of Biosciences. 2018;12(6):102-116.

22. GSI. Geological Survey of India. Sp Pub. 2009;34.

23. ISRO. High Altitude Himalayan Lakes. National Wetland Inventory and Assessment. Space Application Centre, Ahmedabad. 2011.

24. Uttarakhand Jal Sansthan. Chal-Khal: Parampra Ka Punarjivan. Uttarakhand Jal Sansthan, Dehradun. 2016;27.

25. Vani MS, Asthana R. Water Rights and Policy in Uttaranchal: Empowered State and Eroded Public Rights in Kadekodi. Water in Kumaon: Ecology, Value and Rights, (Gynodaya Prakashan, Nainital). 2000;209.

26. Upadhayay A, Bisht P, Pandey G. Uttarakhand ne Jal Prabandhan. In: Janak Pandey, Editor. Social Development. APH publishing corporation, New Delhi. 2002;254-256.

27. Kala R, Kala CP. Indigenous water conservation technology in Sumari Village of Uttaranchal. Indian Journal Traditional Knowledge. 2006;5(3):394-396.

28. Dorjee A, Singh P. Traditional irrigation and water distribution system in Ladakh. Indian Journal of Traditional Knowledge. 2006;5(3):397-402.

29. Chandra S. Planning for integrated water resources development project with special reference to conjunctive use of surface and ground water resources. Central groundwater board, New Delhi. 1987.

30. Upadhyay A, Bisht P. Water Management in Uttarakhand: An overview, Nainital. 2001;7.

31. Radhakrishnan S. The Heart of Hindustan. Madras, GA Natesan. 1936;6:1888-1975.

32. Panday M, Chauhan CS. Traditional hydraulic technology. 2010;104-123. 